\title{
Effects of temperature on the growth and ingestion rates of the newly described mixotrophic dinoflagellate Yihiella yeosuensis and its two optimal prey species
}

\author{
Hee Chang Kang ${ }^{1}$, Hae Jin Jeong ${ }^{1,2, *}$, An Suk Lim³ , Jin Hee Ok ${ }^{1}$, Ji Hyun You' ${ }^{1}$, Sang Ah \\ Park $^{1}$, Sung Yeon Lee ${ }^{1}$ and Se Hee Eom ${ }^{1}$ \\ ${ }^{1}$ School of Earth and Environmental Sciences, College of Natural Sciences, Seoul National University, Seoul 08826, Korea \\ ${ }^{2}$ Research Institute of Oceanography, Seoul National University, Seoul 08826, Korea \\ ${ }^{3}$ Division of Life Science, Gyeongsang National University, Jinju 52828, Korea
}

\begin{abstract}
Water temperature is known to affect the growth and feeding of marine dinoflagellates. Each dinoflagellate species grows well at a certain optimal temperature but dies at very cold and hot temperatures. Thus, changes in water temperatures driven by global warming and extremely high or low temperatures can affect the distribution of dinoflagellates. Yihiella yeosuensis is a mixotrophic dinoflagellate that can feed on only the cryptophyte Teleaulax amphioxeia and the chlorophyte Pyramimonas sp. Furthermore, it grows fast mixotrophically but rarely grows photosynthetically. We explored the direct and indirect effects of water temperature on the growth and ingestion rates of $Y$. yeosuensis feeding on T. amphioxeia and the growth rates of T. amphioxeia and Pyramimonas sp. under 7 different water temperatures (5$35^{\circ} \mathrm{C}$ ). Both the autotrophic and mixotrophic growth rates of Y. yeosuensis on T. amphioxeia were significantly affected by temperature. Under the mixotrophic and autotrophic conditions, Y. yeosuensis survived at $10-25^{\circ} \mathrm{C}$, but died at $5^{\circ} \mathrm{C}$ and $\geq 30^{\circ} \mathrm{C}$. The maximum mixotrophic growth rate of $Y$. yeosuensis on T. amphioxeia $\left(1.16 \mathrm{~d}^{-1}\right)$ was achieved at $25^{\circ} \mathrm{C}$, whereas the maximum autotrophic growth rate $\left(0.16 \mathrm{~d}^{-1}\right)$ was achieved at $15^{\circ} \mathrm{C}$. The maximum ingestion rate of $Y$. yeosuensis on $T$. amphioxeia $\left(0.24 \mathrm{ng} \mathrm{C}\right.$ predator $\left.{ }^{-1} \mathrm{~d}^{-1}\right)$ was achieved at $25^{\circ} \mathrm{C}$. The cells of $T$. amphioxeia survived at $10-25^{\circ} \mathrm{C}$, but died at 5 and $\geq 30^{\circ} \mathrm{C}$. The cells of Pyramimonas sp. survived at $5-25^{\circ} \mathrm{C}$, but died at $30^{\circ} \mathrm{C}$. The maximum growth rate of T. amphioxeia $\left(0.72 \mathrm{~d}^{-1}\right)$ and Pyramimonas sp. $\left(0.75 \mathrm{~d}^{-1}\right)$ was achieved at $25^{\circ} \mathrm{C}$. The abundance of $Y$. yeosuensis is expected to be high at $25^{\circ} \mathrm{C}$, at which its two prey species have their highest growth rates, whereas $Y$. yeosuensis is expected to be rare or absent at $5^{\circ} \mathrm{C}$ or $\geq 30^{\circ} \mathrm{C}$ at which its two prey species do not survive or grow. Therefore, temperature can directly or indirectly affect the population dynamics and distribution of $Y$. yeosuensis.
\end{abstract}

Key Words: Chlorophyte; cryptophyte; feeding; harmful algal bloom; protist; red tide

\section{INTRODUCTION}

Marine dinoflagellates are ubiquitous and a major component of marine ecosystems (Hallegraeff 1993, Taylor et al. 2008, Klueter et al. 2017, Kang et al. 2019b, Lee et al. 2019b). They play diverse roles in marine food webs (Hansen 1991, Jeong et al. 2010, Anderson and MendenDeuer 2017, You et al. 2020a); autotrophic dinoflagellates
(1) \$ This is an Open Access article distributed under the terms of the Creative Commons Attribution Non-Commercial License (http://creativecommons.org/licenses/by-nc/3.0/) which permits unrestricted non-commercial use, distribution, and reproduction in any medium, provided the original work is properly cited.
Received July 7, 2020, Accepted August 20, 2020

*Corresponding Author

E-mail: hjjeong@snu.ac.kr

Tel: +82-2-880-6746, Fax: +82-2-874-9695 
are important primary producers, whereas heterotrophic dinoflagellates are important predators of phytoplankton and bacteria (Levinsen and Nielsen 2002, Montero et al. 2017, Kang et al. 2018, 2019a, Spilling et al. 2018). Mixotrophic dinoflagellates, which perform both photosynthesis and predation, are also important primary producers, prey for diverse predators, and predators of phytoplankton and bacteria (Skovgaard et al. 2000, Seong et al. 2006, Glibert et al. 2009, Ok et al. 2017, Stoecker et al. 2017). Many mixotrophic dinoflagellates often form red tides or harmful algal blooms that cause great losses in diverse industries (Jeong et al. 2017, López-Cortés et al. 2019, Roselli et al. 2020, Sakamoto et al. 2020). The population dynamics and distribution of mixotrophic dinoflagellates are of primary concern to scientists, government officials, and aquafarmers (Li et al. 2000, Heil et al. 2005, Lee et al. 2013, 2019a). Predicting the population dynamics of a mixotrophic dinoflagellate is critical for science and the industry.

In population dynamics models of phytoplankton species, growth and mortality due to predation are two critical parameters (Jeong et al. 2015). The growth rate of a mixotrophic dinoflagellate is affected primarily by prey concentration, temperature, and light intensity (Hansen and Nielsen 1997, Jeong et al. 2005, Baek et al. 2008, Laabir et al. 2011). Dinoflagellate species grow well at an optimal temperature but die at very cold and hot temperatures (Matsubara et al. 2007, Kibler et al. 2012, Jeong et al. 2018b, Lim et al. 2019, Ok et al. 2019, You et al. 2020b). Therefore, changes in water temperature and extremely high or low temperature can critically affect distribution of dinoflagellates. Extremely high water temperature events worldwide are expected to be more intense, frequent, and long-lasting as a consequence of global warming (Belkin 2009, Hansen et al. 2012), and have altered the structure and function of marine ecosystems (McClanahan et al. 2007, Wernberg et al. 2013, Ruthrof et al. 2018). However, the effects of extremely high water temperatures on marine dinoflagellates are still poorly understood. To understand the population dynamics of a mixotrophic dinoflagellate at present and in the near future, the effects of a wide range of water temperatures on the eco-physiological characteristics of dinoflagellates should be determined.

Yihiella yeosuensis was established as a new species in a new genus in 2017 (Jang et al. 2017b). This species is a mixotrophic dinoflagellate that can feed on only the cryptophyte Teleaulax amphioxeia and the chlorophyte Pyramimonas sp. among the tested algal prey species (Jang et al. 2017a). It grows fast mixotrophically but rarely grows photosynthetically (Jang et al. 2017a). Among the 11 heterotrophic protists explored, there were no potential predators that were able to feed on actively swimming $Y$. yeosuensis cells, which escaped via rapid jumps (Jeong et al. 2018a). Furthermore, the results of the transcriptomic analysis showed that when $Y$. yeosuensis cells changed from the vegetative cells to cysts, polyketide synthase and cell-wall biogenesis genes related to antipredation were highly up-regulated (Jang et al. 2019). Thus, predators may not critically affect the population dynamics of the vegetative cells and cysts of $Y$. yeosuensis. In its population dynamics, its growth rate is likely to be more important than mortality due to predation. Prey concentration, a critical biotic factor, is known to significantly affect the growth rates of $Y$. yeosuensis (Jang et al. 2017a). As a critical abiotic factor, temperature is likely to affect the growth and feeding of $Y$. yeosuensis on optimal prey species (direct effect) and also the growth of the prey species (i.e., prey availability, indirect effect). Thus, it is worth exploring the direct and indirect effects of temperature on the growth rates and ingestion rates of Y. yeosuensis and its prey.

We explored the effects of water temperature on the growth and ingestion rates of $Y$. yeosuensis feeding on $T$. amphioxeia and also the growth rates of T. amphioxeia and Pyramimonas sp. under 7 different water temperatures $\left(5-35^{\circ} \mathrm{C}\right)$. Under the mixotrophic (with prey) and autotrophic (without prey) conditions, the optimal temperatures for the maximum mixotrophic and autotrophic growth rates of Y. yeosuensis, as well as the lowest and highest temperatures for its survival, were determined. We also investigated the optimal temperature and temperature range for survival of T. amphioxeia and Pyramimonas sp. The results of the present study provide a basis for understanding the effects of water temperature on the eco-physiological characteristics and population dynamics of $Y$. yeosuensis and its prey species.

\section{MATERIALS AND METHODS}

\section{Culture of organisms}

A clonal culture of Y. yeosuensis YYYS1405, which was isolated from the coastal waters of Yeosu, Korea, in May 2014 (Jang et al. 2017b), was used. A dense culture (approximately 20,000 cells $\mathrm{mL}^{-1}$ ) of $Y$. yeosuensis was transferred every $5 \mathrm{~d}$ to a $270-\mathrm{mL}$ polycarbonate (PC) bottle that contained a fresh culture of T. amphioxeia CR-MAL01 (approximately 100,000 cells $\mathrm{mL}^{-1}$ ). The bottle was placed 
on a shelf at $20^{\circ} \mathrm{C}$ under illumination of $20 \mu \mathrm{mol}$ photons $\mathrm{m}^{-2} \mathrm{~s}^{-1}$ cool-white fluorescent light with a $14: 10 \mathrm{~h}$ lightdark cycle.

The cells of T. amphioxeia CR-MAL01 were isolated from the surface waters of Gomso Bay, Korea (Yih et al. 2004, Jang and Jeong 2020). The cells of Pyramimonas sp. PSSH1204 were isolated from the surface waters of Shiwha Bay, Korea (Jang and Jeong 2020). The cultures of T. amphioxeia and Pyramimonas sp. were maintained in an enriched $\mathrm{f} / 2$-Si seawater medium. The flasks that contained T. amphioxeia CR-MAL01 or Pyramimonas sp. PSSH1204 were filled to capacity, capped, and placed on a shelf at $20^{\circ} \mathrm{C}$, illuminated with an irradiance of $20 \mu \mathrm{mol}$ photons $\mathrm{m}^{-2} \mathrm{~s}^{-1}$ provided by cool white fluorescent light, under a $14: 10 \mathrm{~h}$ light-dark cycle.

The carbon content of Y.yeosuensis, T. amphioxeia, and Pyramimonas sp. were obtained from Jang et al. (2017a) and Lee et al. (2014).

\section{Temperature effects on autotrophic and mixo- trophic growth and ingestion of Yihiella yeos- uensis}

Experiment (Expt) 1 was designed to determine the autotrophic growth rate of $Y$. yeosuensis YYYS1405 (i.e., without prey) and the mixotrophic growth and ingestion rates of Y. yeosuensis on T. amphioxeia as a function of water temperature (Table 1). The initial single high prey concentration at which the growth and ingestion rates of Y.yeosuensis on T. amphioxeia were saturated was chosen (Table 1). Expt 1 was designed with appropriate acclimation periods as shown in Fig. 1. In this experiment, the autotrophic growth rate of T. amphioxeia as a function of water temperature was determined.
A dense culture of $Y$. yeosuensis YYYS1405 (ca. 20,000 cells $\mathrm{mL}^{-1}$ ) growing on T. amphioxeia was transferred to each of the seven 270-mL PC bottles. A dense culture of T. amphioxeia (ca. 100,000 cells $\mathrm{mL}^{-1}$ ) growing in $\mathrm{f} / 2-\mathrm{Si}$ medium was also transferred to each of the seven 270$\mathrm{mL}$ flasks. The target temperatures were established in seven temperature-controlled chambers. Bottles, each containing Y. yeosuensis, and flasks, each containing $T$. amphioxeia, were placed in one of the seven chambers inside which a target temperature was established.

In the preliminary tests, Y. yeosuensis YYYS1405 did not grow at 5,30 , and $35^{\circ} \mathrm{C}$. Thus, in preparation for $5^{\circ} \mathrm{C}$ in Expt 1, Y. yeosuensis cells were subsequently acclimated at $15^{\circ} \mathrm{C}$ for $2 \mathrm{~d}$, at $10^{\circ} \mathrm{C}$ for $5 \mathrm{~d}$, and at $5^{\circ} \mathrm{C}$ for $2 \mathrm{~d}$ at $20 \mu \mathrm{mol}$ photons $\mathrm{m}^{-2} \mathrm{~s}^{-1}$ on a $14: 10 \mathrm{~h}$ light-dark cycle (Fig. 1A). For 30 and $35^{\circ} \mathrm{C}$, Y. yeosuensis cells were subsequently acclimated at $25^{\circ} \mathrm{C}$ for $7 \mathrm{~d}$, and at $30^{\circ} \mathrm{C}$ for $2 \mathrm{~d}$. Furthermore, for $10^{\circ} \mathrm{C}, Y$.yeosuensis cells were subsequently acclimated at $15^{\circ} \mathrm{C}$ for $2 \mathrm{~d}$ and at $10^{\circ} \mathrm{C}$ for $7 \mathrm{~d}$. This gradual acclimation was conducted to avoid any shock that may occur when a large temperature change occurs rapidly. For 15, 20 , and $25^{\circ} \mathrm{C}, \mathrm{Y}$. yeosuensis cells were incubated at each target temperature for $9 \mathrm{~d}$ (Fig. 1A). In preliminary tests, T. amphioxeia also did not grow at 5,30 , and $35^{\circ} \mathrm{C}$. Thus, T. amphioxeia cells were also acclimated in a manner similar to the acclimation of $Y$. yeosuensis cells (Fig. 1B). At 1-3 d intervals after this pre-incubation started, 5-mL aliquots were obtained from each bottle and flask incubated at the target temperature and fixed with $5 \%$ acidic Lugol's solution; subsequently, the abundances of $Y$. yeosuensis and T. amphioxeia were measured.

In Expt 1, the initial concentrations of $Y$. yeosuensis YYYS1405 and T. amphioxeia were obtained using an autopipette with the predetermined volume of culture hav-

Table 1. Design of the experiments

\begin{tabular}{|c|c|c|c|c|c|}
\hline Expt No. & Temperature $\left({ }^{\circ} \mathrm{C}\right)$ & Prey & Prey concentration & Predator & Predator concentration \\
\hline \multirow[t]{3}{*}{1} & $5,10,15,20,25,30,35$ & Teleaulax amphioxeia & $\begin{array}{l}31,347,34,592,33,829 \\
37,029,37,587,33,975 \\
35,590\end{array}$ & Yihiella yeosuensis & $\begin{array}{l}258,265,278,307,367 \\
304,305\end{array}$ \\
\hline & $5,10,15,20,25,30,35$ & Teleaulax amphioxeia & $\begin{array}{l}32,448,31,979,33,608 \\
35,297,37,352,35,238 \\
34,680\end{array}$ & & 0 \\
\hline & $5,10,15,20,25,30,35$ & & 0 & Yihiella yeosuensis & $\begin{array}{l}246,186,236,284,295 \\
298,344\end{array}$ \\
\hline 2 & $5,10,15,20,25,30$ & Pyramimonas sp. & $\begin{array}{c}20,960,17,922,19,740 \\
19,029,21,105,16,218\end{array}$ & & 0 \\
\hline
\end{tabular}

The numbers in the prey (Teleaulax amphioxeia) and predator (Yihiella yeosuensis) columns in Experiment (Expt) and that of Pyramimonas sp. in Expt 2 are the actual initial concentrations (cells $\mathrm{mL}^{-1}$ ) of the prey and predator. The possible effects of prey concentration on the growth and ingestion rates were avoided by providing high prey concentrations at which the growth and ingestion rates of $Y$. yeosuensis on prey were saturated (Jang et al. 2017a). 
A

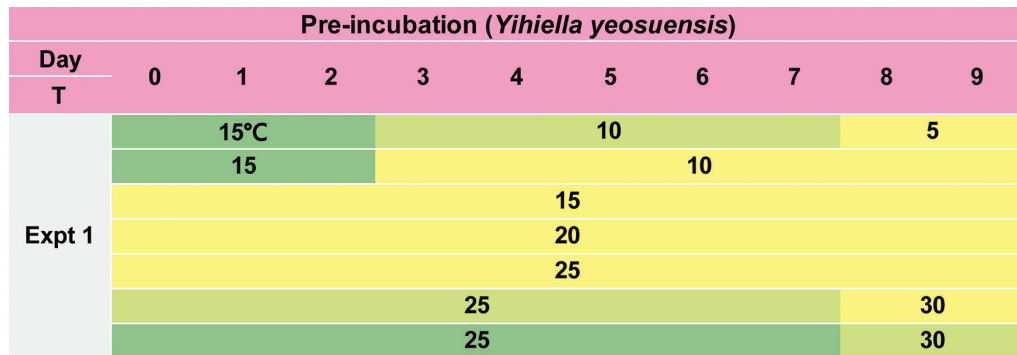

B

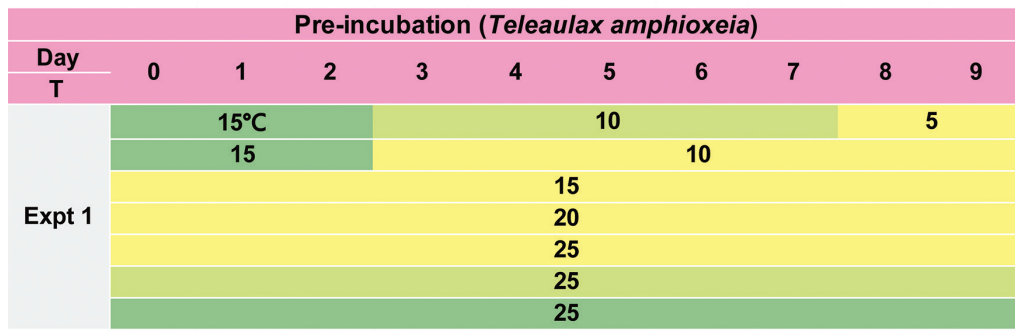

C

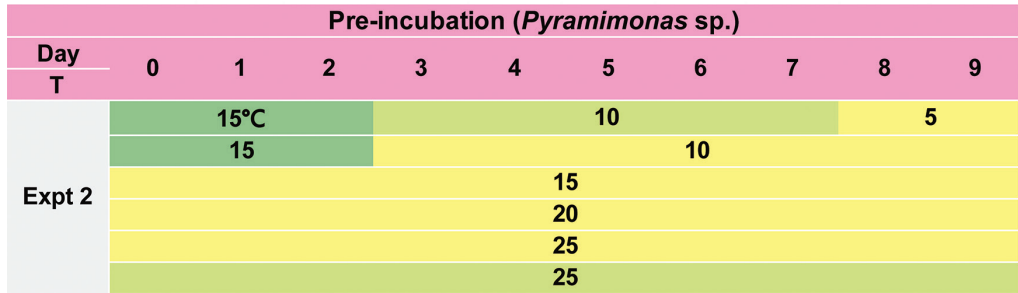

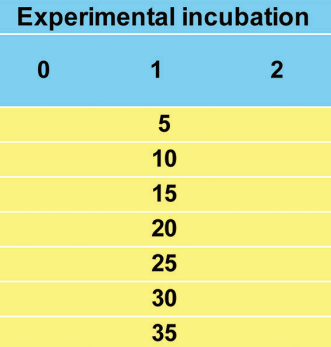
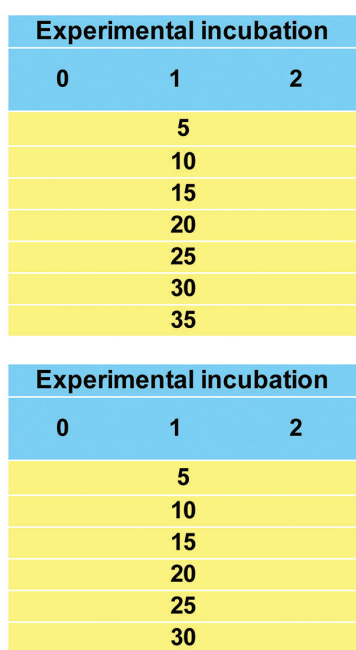

Fig. 1. Data obtained during the pre-incubation and experimental incubation periods when testing the effects of temperature on the growth of Yihiella yeosuensis (A), Teleaulax amphioxeia (B), and Pyramimonas sp. (C). T, temperature $\left({ }^{\circ} \mathrm{C}\right)$. Pink and blue indicate the pre-incubation and experimental incubation periods, respectively. Yellow indicates the period of maintaining the cultures at a target temperature. Bright and dark green indicate the periods of temporarily maintaining the cultures to avoid possible inhibition at certain target temperatures.

ing a known cell density to the experimental PC bottles (Table 1). Triplicate 42-mL experimental PC bottles (mixtures of Y. yeosuensis and T. amphioxeia), triplicate prey control bottles (T. amphioxeia only), and triplicate predator control bottles (Y. yeosuensis only) were set up at each temperature. Similar water conditions were ensured by filtering each culture of the predator through a $0.2-\mu \mathrm{m}$ disposable membrane filter (ADVANTEC; Toyo Rhoshi Kaisha, Ltd., Tokyo, Japan) and then adding this filtered water to the prey control bottles at the same water volume as that of the predator culture added to the experiment and predator control bottles (You et al. 2020b). The prey cultures were also filtered in the same manner and then added to the predator control bottles. Next, $10-\mathrm{mL}$ of $\mathrm{f} / 2$ Si medium was added to all the experimental and control bottles; they were then filled to capacity with freshly-filtered seawater, capped, and then placed on a shelf at 20 $\mu \mathrm{mol}$ photons $\mathrm{m}^{-2} \mathrm{~s}^{-1}$ on a $14: 10 \mathrm{~h}$ light-dark cycle for $2 \mathrm{~d}$ at each target temperature. The actual predator and prey densities (cells $\mathrm{mL}^{-1}$ ) at the beginning of the experiment and after a two-day incubation period were determined by obtaining 5 - and 10-mL aliquots from each bottle and fixing them with $5 \%$ acidic Lugol's solution; all or $\geq 300$ Y. yeosuensis and T. amphioxeia cells were enumerated using a Sedgewick-Rafter counting chamber. The bottles were refilled again to capacity with freshly filtered seawater after subsampling at the beginning of the experiment, capped, and then incubated under the same conditions described above.

The specific growth rate of Y. yeosuensis $\left(\mu, \mathrm{d}^{-1}\right)$ was calculated following Heinbokel (1978):

$$
\mu\left(d^{-1}\right)=\left[\operatorname{Ln}\left(C_{t} / C_{0}\right)\right] / t
$$

, where $\mathrm{C}_{0}$ is the initial concentration of Y. yeosuensis and $\mathrm{C}_{\mathrm{t}}$ is the final concentration after time $\mathrm{t}(2 \mathrm{~d})$.

The ingestion rates of $Y$. yeosuensis on T. amphioxeia were calculated following Lim et al. (2018) by using the modified equations of Frost (1972) and Heinbokel (1978) because diluting the cultures by refilling them with sea water after subsampling was considered in the growth and ingestion rate calculations. The incubation time for 
calculating the ingestion rates was the same as that for calculating the growth rates. The specific growth rate of T. amphioxeia $\left(\mu, \mathrm{d}^{-1}\right)$ was also calculated as described above.

Three milliliter aliquots were removed from each bottle after 2-d incubations and transferred into confocal dishes (SPL100350; SPL Life Sciences Co., Ltd., Pocheon, Korea). The cells of $Y$. yeosuensis and T. amphioxeia were photographed on the confocal dishes using a digital camera (Zeiss AxioCam HRc 5; Carl Zeiss Ltd., Göttingen, Germany) and a microscope at 1,000× magnification.

\section{Temperature effects on autotrophic growth of Pyramimonas sp.}

Expt 2 was designed to determine the autotrophic growth rate of Pyramimonas sp. PSSH1204 as a function of water temperature (Table 1). The initial single high concentration at which the growth and ingestion rates of Y. yeosuensis on Pyramimonas sp. were saturated was chosen (Table 1). In the preliminary tests, the Pyramimonas sp. strain did not grow at 5 and $30^{\circ} \mathrm{C}$. Expt 2 was designed accordingly, with appropriate acclimation periods as shown in Fig. 1C.

In preparation for $5^{\circ} \mathrm{C}$ in Expt 2, the Pyramimonas sp. cells were subsequently acclimated at $15^{\circ} \mathrm{C}$ for $2 \mathrm{~d}$, at $10^{\circ} \mathrm{C}$ for $5 \mathrm{~d}$, and at $5^{\circ} \mathrm{C}$ for $2 \mathrm{~d}$ at $20 \mu \mathrm{mol}$ photons $\mathrm{m}^{-2}$ $\mathrm{s}^{-1}$ on a $14: 10 \mathrm{~h}$ light-dark cycle (Fig. $1 \mathrm{C}$ ). For $30^{\circ} \mathrm{C}$, the Pyramimonas sp. cells were acclimated at $25^{\circ} \mathrm{C}$ for $9 \mathrm{~d}$ because all the Pyramimonas sp. cells were dead after a 1-d incubation period. For $10^{\circ} \mathrm{C}$, Pyramimonas sp. cells were subsequently acclimated at $15^{\circ} \mathrm{C}$ for $2 \mathrm{~d}$ and at $10^{\circ} \mathrm{C}$ for 7 d. For 15,20 , and $25^{\circ} \mathrm{C}$, the Pyramimonas sp. cells were incubated at each target temperature for $9 \mathrm{~d}$ (Fig. 1C). At 1-3 d intervals after this pre-incubation period started, 5 -mL aliquots were obtained from each flask incubated at the target temperature and fixed with 5\% acidic Lugol's solution, and the abundance of Pyramimonas sp. was determined.

In Expt 2, the initial concentrations of Pyramimonas sp. were achieved as described above (Table 1). Triplicate 42-mL experimental PC bottles (Pyramimonas sp.) were set up at each temperature. The bottles were then filled to capacity with freshly-filtered seawater, capped, and then placed on a shelf at $20 \mu \mathrm{mol}$ photons $\mathrm{m}^{-2} \mathrm{~s}^{-1}$ on a $14: 10 \mathrm{~h}$ light-dark cycle for $2 \mathrm{~d}$ at each target temperature. The actual densities (cells $\mathrm{mL}^{-1}$ ) at the beginning of the experiment and after a 2-d incubation period were determined by obtaining 5 - and $10-\mathrm{mL}$ aliquots from each bottle and fixing them with 5\% acidic Lugol's solu- tion; $\geq 300$ Pyramimonas sp. cells were enumerated using a Sedgewick-Rafter counting chamber. The bottles were refilled again to capacity with freshly-filtered seawater after subsampling at the beginning of the experiment, capped, and then incubated under the same conditions described above. The specific growth rate of Pyramimonas sp. $\left(\mu, \mathrm{d}^{-1}\right)$ was calculated as described above.

Three milliliter aliquots were removed from each bottle after 2-d incubations and transferred into confocal dishes, and Pyramimonas sp. cells were photographed on the confocal dishes using a digital camera and a microscope at $1,000 \times$ magnification.

\section{Statistical analysis}

Univariate analyses were used to investigate the effects of water temperature on the autotrophic growth rates of $Y$. yeosuensis, mixotrophic growth rates and ingestion rates of $Y$. yeosuensis on T. amphioxeia, and the growth rates of prey T. amphioxeia and Pyramimonas sp. Two assumptions, such as normality and homogeneity of variance, were tested using Shapiro-Wilk's W and Levene's test, respectively. A parametric one-way analysis of variance (ANOVA) with Tukey's honestly significant difference (HSD) post-hoc test was conducted if the data satisfied those two assumptions. If the data satisfied only the normality assumption, a Welch's one-way ANOVA and Games-Howell post-hoc test were used. If the data did not satisfy the normality assumption, a non-parametric Kruskal-Wallis test and a Mann-Whitney U comparison with the Bonferroni correction was performed.

A multivariate analysis of variance (MANOVA, Pillai's trace statistics) was performed to investigate the differential effects of water temperature on the autotrophic and mixotrophic growth rates of $Y$. yeosuensis. The assumptions of normality and homogeneity for the MANOVA were checked using Shapiro-Wilk's W and Box's M test, respectively.

An independent-samples t-test was conducted to assess the significant differences between the autotrophic and mixotrophic growth rates of $Y$. yeosuensis, and between the ingestion rates of $Y$. yeosuensis on T. amphioxe$i a$ and zero at each water temperature. The data between the ingestion rates at $35^{\circ} \mathrm{C}$ and zero were not assessed because the ingestion rates at the temperature were zero. All statistical analyses were performed using SPSS version 25.0 (IBM Corp., Armonk, NY, USA). The criterion for statistical significance was $\mathrm{p}<0.05$. 

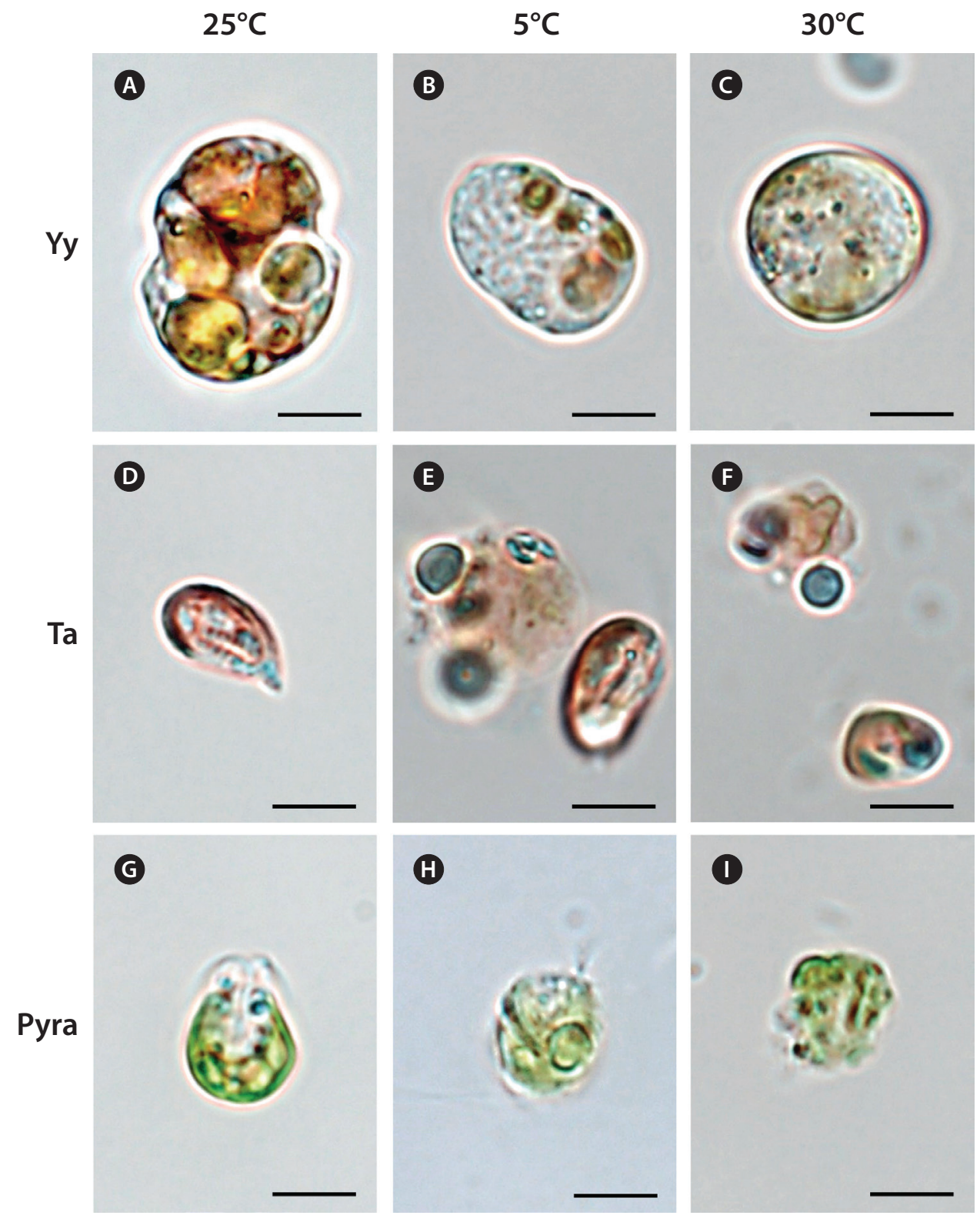

Fig. 2. Light micrographs of Yihiella yeosuensis (Yy) (A-C), Teleaulax amphioxeia (Ta) (D-F), and Pyramimonas sp. (Pyra) (G-I) cells incubated for 2 d at $25(A, D, G), 5(B, E, H)$, and $30^{\circ} \mathrm{C}(C, F, I)$ at $20 \mu \mathrm{mol}$ photons $\mathrm{m}^{-2} \mathrm{~s}^{-1}$. The cells of $Y$. yeosuensis swelled at 5 and $30^{\circ} \mathrm{C}$ and, therefore, the sharply depressed cingulum was seen in (A), but not in (B) and (C). Many T. amphioxeia cells decomposed at 5 and $30^{\circ} \mathrm{C}(\mathrm{E}, \mathrm{F})$. Many Pyramimonas sp. cells decomposed at 5 and $30^{\circ} \mathrm{C}(\mathrm{H}, \mathrm{I})$. Scale bars represent: $\mathrm{A}-\mathrm{I}, 5 \mu \mathrm{m}$.

\section{RESULTS}

\section{Temperature effects on autotrophic and mixo- trophic growth and ingestion of Yihiella yeos- uensis}

The cells of $Y$. yeosuensis YYYS1405 had normal shapes at $10-25^{\circ} \mathrm{C}$, with a distinct cingulum, but they were swollen and had a spherical shape without a distinct cingu- lum at $5^{\circ} \mathrm{C}$ or $\geq 30^{\circ} \mathrm{C}$ (Fig. $2 \mathrm{~A}-\mathrm{C}$ ).

The autotrophic growth rates of Y. yeosuensis YYYS1405 increased from $-0.32 \mathrm{~d}^{-1}$ at $5^{\circ} \mathrm{C}$ to $0.16 \mathrm{~d}^{-1}$ at $15^{\circ} \mathrm{C}$, slightly decreased to $0.09-0.10 \mathrm{~d}^{-1}$ at $20-25^{\circ} \mathrm{C}$, and greatly decreased to $-0.61 \mathrm{~d}^{-1}$ at $30^{\circ} \mathrm{C}$ and $-4.07 \mathrm{~d}^{-1}$ at $35^{\circ} \mathrm{C}$ (Fig. 3A). The autotrophic growth rates were significantly affected by water temperature (one-way ANOVA, $\mathrm{F}_{6,14}=1,130.27$, $\mathrm{p}$ $<0.001$ ) and were divided into four different temperature groups (Tukey's HSD post-hoc test, $\mathrm{p}<0.05$ ) (Fig. 3A). 

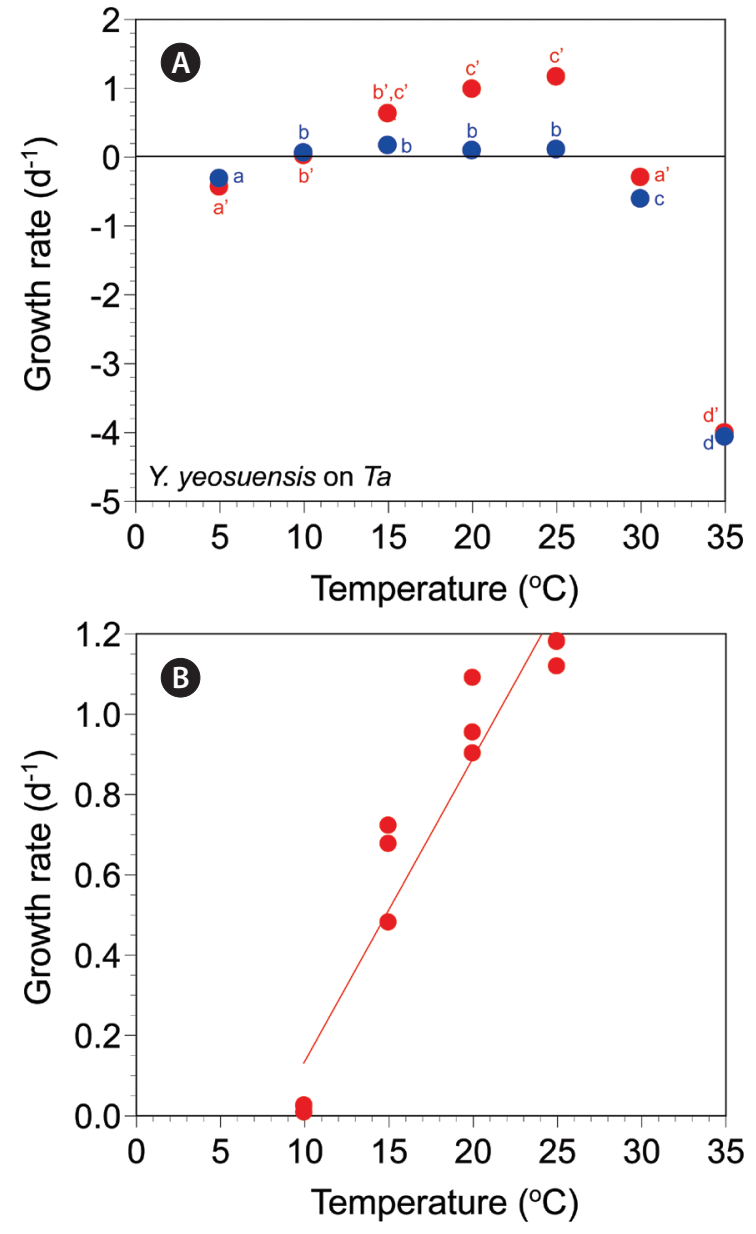

Fig. 3. Specific autotrophic growth rates of Yihiella yeosuensis (blue circles) and mixotrophic growth rates of $Y$. yeosuensis on Teleaulax amphioxeia ( $\mathrm{Ta}$, red circles) as a function of water temperature $\left(\mathrm{T},{ }^{\circ} \mathrm{C}\right)$ at $5-35^{\circ} \mathrm{C}(\mathrm{A})$ and $10-25^{\circ} \mathrm{C}$ (B). Symbols represent treatment means \pm 1 standard error. The linear regression equation in $(B)$ is growth rate $\left(d^{-1}\right)=0.0756 \times(T)-0.627, r^{2}=0.917$. Significantly different groups based on post-hoc tests of ANOVAs: autotrophic growth rate using the Tukey's honestly significant difference post-hoc test, 5 (a), 10-25 (b), 30 (c), $35^{\circ} \mathrm{C}$ (d); mixotrophic growth rate using the Games-Howell post-hoc test, $5\left(a^{\prime}\right), 10\left(b^{\prime}\right), 15\left(b^{\prime}, c^{\prime}\right), 20-25\left(c^{\prime}\right), 30\left(a^{\prime}\right), 35^{\circ} \mathrm{C}\left(d^{\prime}\right)$.

The mixotrophic growth rates of Y.yeosuensis YYYS1405 on T. amphioxeia at $5-35^{\circ} \mathrm{C}$ ranged from -4.01 to $1.16 \mathrm{~d}^{-1}$ (Fig. 3A). The rates were positive at $10-25^{\circ} \mathrm{C}$, but negative at $5^{\circ} \mathrm{C}$ and $30-35^{\circ} \mathrm{C}$. The maximum mixotrophic growth rate was achieved at $25^{\circ} \mathrm{C}$. The rates were significantly affected by temperature (Welch's one-way ANOVA, $\mathrm{F}_{6,5.91}=$ $30,300.48, \mathrm{p}<0.001$ ); the rates were subdivided into four different temperature groups (Games-Howell post-hoc test, $\mathrm{p}<0.05$ ) (Fig. 3A).

The effects of temperature were significantly different between the autotrophic and mixotrophic growth rates

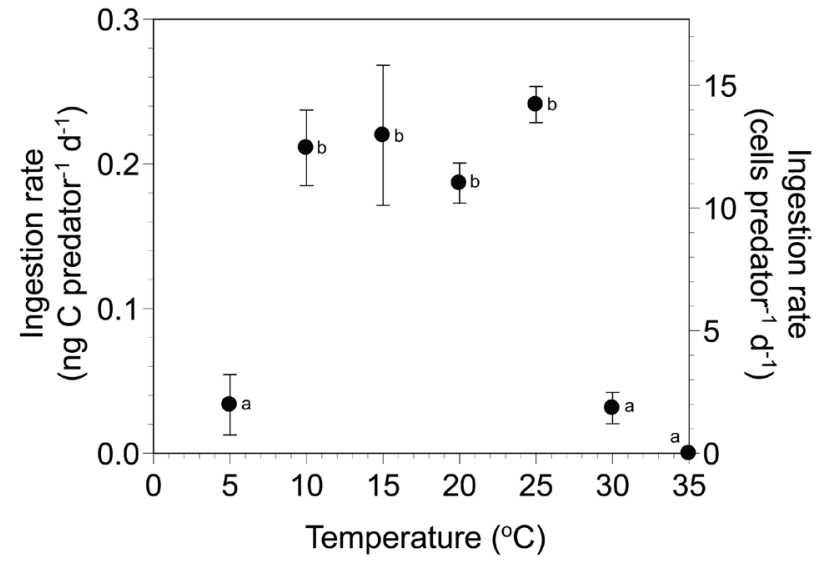

Fig. 4. Ingestion rates of Yihiella yeosuensis on Teleaulax amphioxeia as a function of water temperature. Symbols represent treatment means \pm 1 standard error. Significantly different groups based on the Tukey's honestly significant difference post-hoc test of a one-way ANOVA: 5 and $30-35$ (a); $10-25^{\circ} \mathrm{C}$ (b).

of $Y$. yeosuensis YYYS1405 (MANOVA, Pillai's Trace $=0.99$, $\mathrm{F}_{2,13}=741.17, \mathrm{p}<0.001$ ) (Fig. 3A).

At 10 and $35^{\circ} \mathrm{C}$, the autotrophic and mixotrophic growth rates of $Y$. yeosuensis YYYS1405 were not significantly different (two-tailed t test, $\mathrm{t} 2.02=-0.48, \mathrm{p}=0.678$ at $10^{\circ} \mathrm{C} ; \mathrm{t} 4=1.94, \mathrm{p}=0.125$ at $35^{\circ} \mathrm{C}$ ) (Fig. $3 \mathrm{~A}$ ). However, at $5^{\circ} \mathrm{C}$ and from 15 to $30^{\circ} \mathrm{C}$, the autotrophic and mixotrophic growth rates of $Y$. yeosuensis were significantly different (two-tailed t test, $\mathrm{t} 4=-3.19, \mathrm{p}=0.033$ at $5^{\circ} \mathrm{C} ; \mathrm{t} 4=$ 5.88, $\mathrm{p}=0.004$ at $15^{\circ} \mathrm{C} ; \mathrm{t} 4=10.76, \mathrm{p}<0.001$ at $20^{\circ} \mathrm{C} ; \mathrm{t} 4=$ $21.75, \mathrm{p}<0.001$ at $25^{\circ} \mathrm{C} ; \mathrm{t} 4=7.18, \mathrm{p}=0.002$ at $30^{\circ} \mathrm{C}$ ) (Fig. $3 \mathrm{~A})$. The slope of the linear regression line for the mixotrophic growth rates of Y. yeosuensis YYYS1405 at $10-25^{\circ} \mathrm{C}$ was 0.0756 (Fig. 3B).

The ingestion rates of Y. yeosuensis YYYS1405 on T. amphioxeia at $5-35^{\circ} \mathrm{C}$ ranged from 0 to $0.24 \mathrm{ng} \mathrm{C}$ predator $^{-1}$ $\mathrm{d}^{-1}$ (Fig. 4), and the maximum rate was at $25^{\circ} \mathrm{C}$. The ingestion rates at $5-35^{\circ} \mathrm{C}$ were significantly affected by water temperature (one-way ANOVA, $\mathrm{F}_{6,14}=19.64, \mathrm{p}<0.001$ ) and were divided into two different temperature groups (Tukey's HSD post-hoc test, p < 0.05) (Fig. 4). However, the ingestion rates at $10-25^{\circ} \mathrm{C}$ were not significantly affected by water temperature (one-way ANOVA, $\mathrm{F}_{3,8}=0.63$, $\mathrm{p}=0.633$ ). The ingestion rates of Y. yeosuensis on T. amphioxeia were significantly higher than zero at $10-30^{\circ} \mathrm{C}$ (one-tailed t test, $\mathrm{t} 4=1.61, \mathrm{p}=0.091$ at $5^{\circ} \mathrm{C}$; $\mathrm{t} 2=8.10, \mathrm{p}=$ 0.008 at $10^{\circ} \mathrm{C} ; \mathrm{t} 4=4.54, \mathrm{p}=0.005$ at $15^{\circ} \mathrm{C} ; \mathrm{t} 2=13.70, \mathrm{p}=$ 0.003 at $20^{\circ} \mathrm{C} ; \mathrm{t} 2=18.80, \mathrm{p}=0.002$ at $25^{\circ} \mathrm{C} ; \mathrm{t} 4=2.92, \mathrm{p}=$ 0.022 at $30^{\circ} \mathrm{C}$ ). 

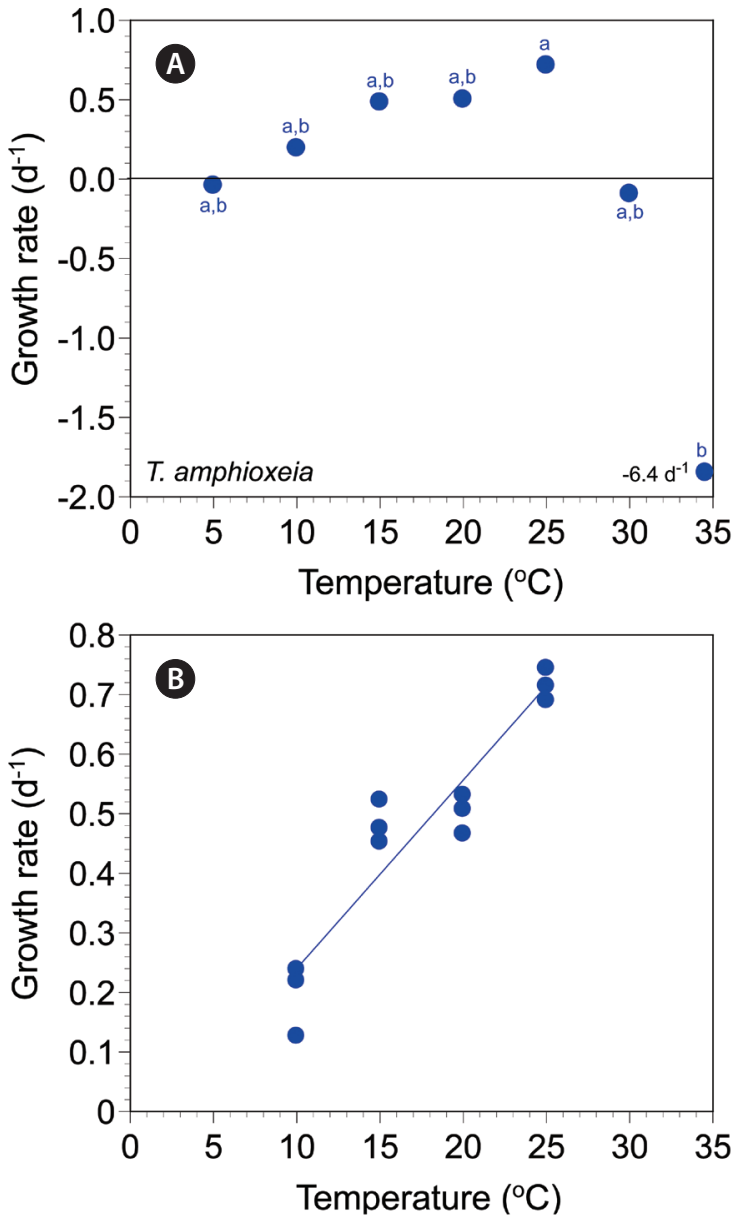

Fig. 5. Specific growth rates of Teleaulax amphioxeia as a function of water temperature $\left(\mathrm{T},{ }^{\circ} \mathrm{C}\right)$ at $5-35^{\circ} \mathrm{C}(\mathrm{A})$ and $10-25^{\circ} \mathrm{C}(\mathrm{B})$. Symbols represent treatment means \pm 1 standard error. The linear regression equation in $(B)$ is growth rate $\left(d^{-1}\right)=0.0316 \times(T)-0.0796, r^{2}=0.882$. Significantly different groups based on Mann-Whitney $\mathrm{U}$ comparisons with the Bonferroni correction of the Kruskal-Wallis test: 5-20 and $30(a, b) ; 25(a) ; 35^{\circ} \mathrm{C}(b)$.

\section{Temperature effects on autotrophic growth of Teleaulax amphioxeia and Pyramimonas sp.}

The cells of T. amphioxeia CR-MAL01 at $10-25^{\circ} \mathrm{C}$ had normal shapes, but many cells decomposed at $5^{\circ} \mathrm{C}$ and $\geq 30^{\circ} \mathrm{C}$ (Fig. 2D-F).

The autotrophic growth rates of T. amphioxeia CRMAL01 at $5-35^{\circ} \mathrm{C}$ ranged from -6.38 to $0.72 \mathrm{~d}^{-1}$ (Fig. 5A). The rates were positive at $10-25^{\circ} \mathrm{C}$, but negative at $5^{\circ} \mathrm{C}$ and $30-35^{\circ} \mathrm{C}$. The maximum autotrophic growth rate was achieved at $25^{\circ} \mathrm{C}$. The rates were significantly affected by temperature (Kruskal-Wallis test, $H_{6}=19.33, \mathrm{p}=0.004$ ); the rates were subdivided into two different temperature groups (Mann-Whitney $U$ test with Bonferroni's correc-
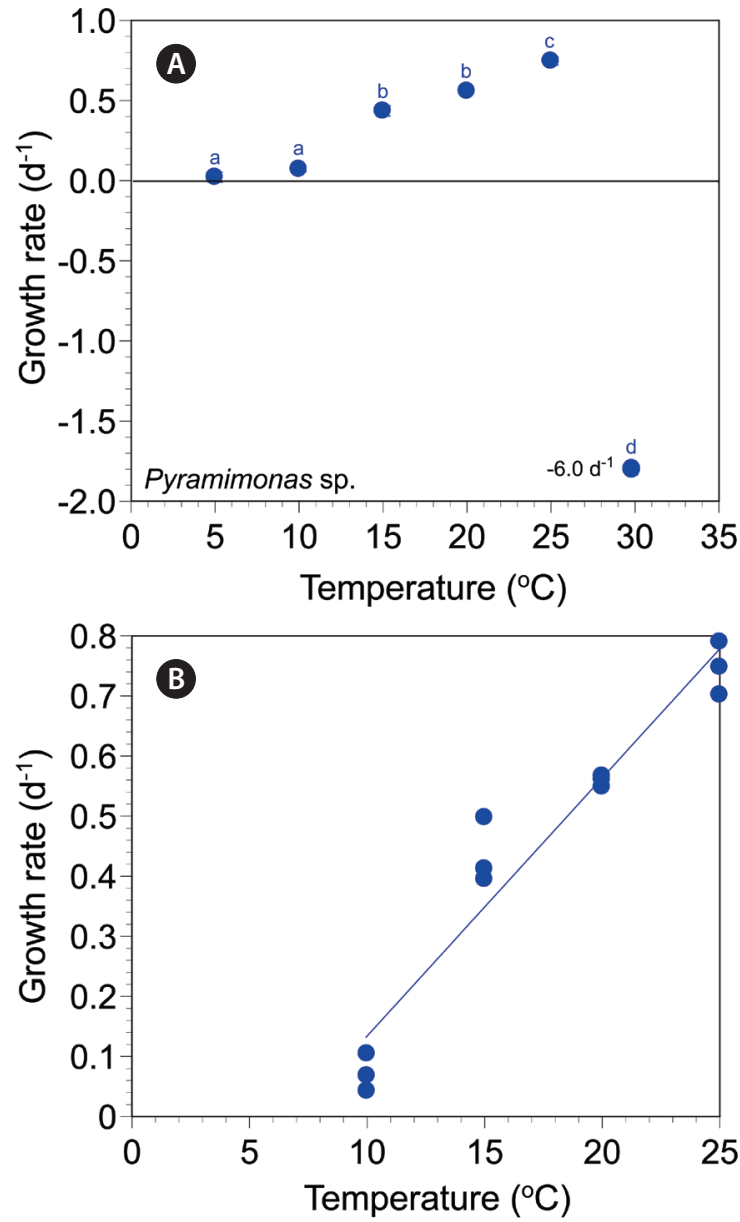

Fig. 6. Specific growth rates of Pyramimonas sp. as a function of water temperature $\left(\mathrm{T},{ }^{\circ} \mathrm{C}\right)$ at $5-30^{\circ} \mathrm{C}(\mathrm{A})$ and $10-25^{\circ} \mathrm{C}(\mathrm{B})$. Symbols represent treatment means \pm 1 standard error. The linear regression equation in (B) is growth rate $\left(d^{-1}\right)=0.0430 \times(T)-0.299, r^{2}=0.934$. Significantly different groups based on the Tukey's honestly significant difference post-hoc test of a one-way ANOVA: 5-10 (a); 15-20 (b); 25 (c); $30^{\circ} \mathrm{C}(\mathrm{d})$.

tion, $\mathrm{p}<0.05$ ) (Fig. 5A). The slope of the linear regression line for the growth rates of T. amphioxeia at $10-25^{\circ} \mathrm{C}$ was 0.0316 (Fig. 5B).

The cells of Pyramimonas sp. PSSH1204 at $10-25^{\circ} \mathrm{C}$ had normal shapes, but some cells decomposed at $5^{\circ} \mathrm{C}$ and many cells at $30^{\circ} \mathrm{C}$ (Fig. 2G-I).

The autotrophic growth rates of Pyramimonas sp. PSSH1204 at $5-30^{\circ} \mathrm{C}$ ranged from -5.99 to $0.75 \mathrm{~d}^{-1}$ (Fig. $6 \mathrm{~A})$. The rates were positive at $5-25^{\circ} \mathrm{C}$, but negative at $30^{\circ} \mathrm{C}$. The maximum autotrophic growth rate was achieved at $25^{\circ} \mathrm{C}$. The rates were significantly affected by temperature (one-way ANOVA, $\mathrm{F}_{5,12}=7,580.15, \mathrm{p}<0.001$ ); the rates were subdivided into four different temperature groups (Tukey's HSD post-hoc test, $\mathrm{p}<0.05$ ) (Fig. 6A). The 
slope of the linear regression line for the growth rates of Pyramimonas sp. at $10-25^{\circ} \mathrm{C}$ was 0.0430 (Fig. 6B).

\section{DISCUSSION}

The present study showed that $Y$. yeosuensis YYYS1405 grew at $10-25^{\circ} \mathrm{C}$ regardless of the presence of prey cells, but did not grow at $5^{\circ} \mathrm{C}$ or $30-35^{\circ} \mathrm{C}$. However, the mixotrophic growth rates of $Y$. yeosuensis on T. amphioxeia at $15-30^{\circ} \mathrm{C}$ were much greater than the autotrophic growth rates at the same temperatures, whereas both rates were similar at 10 and $35^{\circ} \mathrm{C}$. Thus, the growth rate of $Y$. yeosuensis was affected by both prey (i.e., indirect effect) and water temperature (direct effect).

In the water samples that were seasonally collected from 28 stations in the East, West, and South Seas of Korea and Jeju Island from April 2015 to October 2018, Y. yeosuensis were present when water temperatures were 2.3-28. $0^{\circ} \mathrm{C}$, but the highest abundance of $Y$. yeosuensis was found when the water temperature was $25.0^{\circ} \mathrm{C}$ (Jang and Jeong 2020). In the present study, some cells of $Y$. yeosuensis were alive at $5^{\circ} \mathrm{C}$, although the growth rate was negative. Therefore, in natural environments, some Y. yeosuensis cells may tolerate a temperature of $2.3^{\circ} \mathrm{C}$ or cysts suspended in water columns might be detected.

Interestingly, the optimal temperatures for the maximum growth rates of T. amphioxeia and Pyramimonas sp. as well as the lowest and highest temperatures for the survival of these two prey species are almost same as for Y. yeosuensis. Furthermore, in Jang and Jeong (2020), the water temperatures at which T. amphioxeia and Pyramimonas sp. were present (1.1-28.0 and $3.5-27.0^{\circ} \mathrm{C}$, respectively) and also those at which the highest abundances of T. amphioxeia and Pyramimonas sp. were found $\left(23.3\right.$ and $25.0^{\circ} \mathrm{C}$, respectively) were very similar to those of $Y$. yeosuensis. The cells of $Y$. yeosuensis grew fast when fed on T. amphioxeia or Pyramimonas sp., but did not grow well without these prey (Jang et al. 2017a). Thus, $Y$. yeosuensis may have evolved to survive in the range of the water temperatures in which T. amphioxeia or Pyramimonas sp. survive. Furthermore, Y. yeosuensis may have evolved to be abundant at the water temperature at which T. amphioxeia or Pyramimonas sp. are abundant. Similarly, the mixotrophic dinoflagellate Alexandrium pohangense is known to grow at $15-30^{\circ} \mathrm{C}$, at which its only prey, Margalefidinium (Cochlodinium) polykrikoides, can grow (Kim et al. 2004, Lim et al. 2019). It may be a survival strategy for a predator to adapt to the range of water temperatures in which its prey species survives.
In the order Suessiales, there have been several studies on the effects of water temperature on the survival and growth of Polarella glacialis and several dinoflagellate species in the genus Symbiodinium, the name of which has recently been changed to Breviolum, Cladocopium, Durusdinium, Effrenium, Fugacium, and Gerakladium, but few studies on those in other genera (Supplementary Table S1). Cells of $P$. glacialis can survive at $4^{\circ} \mathrm{C}$, at which Y. yeosuensis does not survive (Zheng et al. 2012). Meanwhile, many species in the genera Symbiodinium, Breviolum, Cladocopium, Durusdinium, Effrenium, and Fugacium can survive at $30^{\circ} \mathrm{C}$, unlike $Y$. yeosuensis (Robison and Warner 2006, Rogers and Davis 2006, McBride et al. 2009, Karim et al. 2015, Nitschke et al. 2015, DíazAlmeyda et al. 2017, Grégoire et al. 2017). Furthermore, some species such as Symbiodinium microadriaticum, S. necroappetens, S. linuchae, and S. pilosum can survive at $\geq 32^{\circ} \mathrm{C}$. Most of these species are symbiotic partners of corals, sea anemone, or jellyfish (Robison and Warner 2006, Díaz-Almeyda et al. 2017). Thus, the water temperatures at which they survive may be affected by the distribution of their hosts. Effrenium voratum (Symbiodinium voratum and S. californium) is a free-living species and a mixotrophic dinoflagellate (Jeong et al. 2014, LaJeunesse et al. 2018). This species can survive at $5-30^{\circ} \mathrm{C}$ (McBride et al. 2009). Thus, E. voratum has a temperature range for survival slightly wider than that of $Y$. yeosuensis.

The ingestion rates of $Y$. yeosuensis on T. amphioxeia at $10-25^{\circ} \mathrm{C}$ were not significantly affected by water temperature, although those at $5-35^{\circ} \mathrm{C}$ were. The mixotrophic growth rates of $Y$. yeosuensis on T. amphioxeia at $10-25^{\circ} \mathrm{C}$ continuously increased. Therefore, the gross growth efficiency of $Y$. yeosuensis at $10-25^{\circ} \mathrm{C}$ is likely to increase. No major differences in the ingestion rates of mixotrophic dinoflagellates were found in A. pohangense, Gymnodinium smaydae, and Takayama helix, though there was a continuous increase in their mixotrophic growth rates (Lim et al. 2019, Ok et al. 2019, You et al. 2020b). The activity of enzymes related to the conversion of ingested prey carbon to predator body carbon is likely to increase with increasing temperatures in a range supporting positive growth.

The slope of the regression line with the growth rate of $Y$. yeosuensis as a function of temperature $(0.076)$ is similar to that of the dinoflagellates Paragymnodinium shiwhaense (0.077) and Prorocentrum hoffmannianum (0.071), but greater than that of the other dinoflagellates (0.006-0.048) (Jeong et al. 2018b). Therefore, the growth rate of $Y$. yeosuensis is more sensitive to a change in water temperature than the other dinoflagellates, except for $P$. 
shiwhaense and P. hoffmannianum.

From 1965 to 2010, the water temperature in the coastal waters of Yeosu from which Y. yeosuensis YYYS1405 was isolated has increased at a rate of $0.0305 \mathrm{y}^{1}$ (Seong et al. 2014). From 2015-2019, the water temperature in the coastal waters of Yeosu ranged from 3.65 to $29.77^{\circ} \mathrm{C}$ (Korea Hydrographic and Oceanographic Agency 2020). Theoretically, the water temperature is likely to reach $30^{\circ} \mathrm{C}$ within $8 \mathrm{y}$. Thus, global warming may limit the distribution of $Y$. yeosuensis during summers in the near future. It is worth testing whether the abundance of $Y$. yeosuensis reduces or whether its cells are absent when water temperatures largely increase during the global warming period.

\section{ACKNOWLEDGEMENTS}

This research was supported by the Useful Dinoflagellate program of Korea Institute of Marine Science and Technology Promotion (KIMST) funded by the Ministry of Oceans and Fisheries (MOF) and the National Research Foundation (NRF) funded by the Ministry of Science and ICT (NRF-2017R1E1AlA01074419) award to HJJ.

\section{SUPPLEMENTARY MATERIALS}

Supplementary Table S1. Effect of water temperature $\left(\mathrm{T},{ }^{\circ} \mathrm{C}\right)$ on the growth rate (GR) of the dinoflagellate species in the order Suessiales (https://e-algae.org).

\section{REFERENCES}

Anderson, S. R. \& Menden-Deuer, S. 2017. Growth, grazing, and starvation survival in three heterotrophic dinoflagellate species. J. Eukaryot. Microbiol. 64:213-225.

Baek, S. H., Shimode, S. \& Kikuchi, T. 2008. Growth of dinoflagellates, Ceratium furca and Ceratium fusus in Sagami Bay, Japan: the role of temperature, light intensity and photoperiod. Harmful Algae 7:163-173.

Belkin, I. M. 2009. Rapid warming of large marine ecosystems. Prog. Oceanogr. 81:207-213.

Díaz-Almeyda, E. M., Prada, C., Ohdera, A. H., Moran, H., Civitello, D. J., Iglesias-Prieto, R., Carlo, T. A., LaJeunesse, T. C. \& Medina, M. 2017. Intraspecific and interspecific variation in thermotolerance and photoacclimation in Symbiodinium dinoflagellates. Proc. R. Soc. B Biol. Sci. 284:20171767.
Frost, B. W. 1972. Effects of size and concentration of food particles on the feeding behavior of the marine planktonic copepod Calanus pacificus. Limnol. Oceanogr. 17:805-815.

Glibert, P. M., Burkholder, J. M., Kana, T. M., Alexander, J., Skelton, H. \& Shilling, C. 2009. Grazing by Karenia brevis on Synechococcus enhances its growth rate and may help to sustain blooms. Aquat. Microb. Ecol. 55:17-30.

Grégoire, V., Schmacka, F., Coffroth, M. A. \& Karsten, U. 2017. Photophysiological and thermal tolerance of various genotypes of the coral endosymbiont Symbiodinium sp. (Dinophyceae). J. Appl. Phycol. 29:1893-1905.

Hallegraeff, G. M. 1993. A review of harmful algal blooms and their apparent global increase. Phycologia 32:79-99.

Hansen, J., Sato, M. \& Ruedy, R. 2012. Perception of climate change. Proc. Natl. Acad. Sci. U. S. A. 109:E2415-E2423.

Hansen, P. J. 1991. Quantitative importance and trophic role of heterotrophic dinoflagellates in a coastal pelagial food web. Mar. Ecol. Prog. Ser. 73:253-261.

Hansen, P. J. \& Nielsen, T. G. 1997. Mixotrophic feeding of Fragilidium subglobosum (Dinophyceae) on three species of Ceratium: effects of prey concentration, prey species and light intensity. Mar. Ecol. Prog. Ser. 147:187196.

Heil, C. A., Glibert, P. M. \& Fan, C. 2005. Prorocentrum minimum (Pavillard) Schiller: a review of a harmful algal bloom species of growing worldwide importance. Harmful Algae 4:449-470.

Heinbokel, J. F. 1978. Studies on the functional role of tintinnids in the Southern California Bight. I. Grazing and growth rates in laboratory cultures. Mar. Biol. 47:177189.

Jang, S. H. \& Jeong, H. J. 2020. Spatio-temporal distributions of the newly described mixotrophic dinoflagellate Yihiella yeosuensis (Suessiaceae) in Korean coastal waters and its grazing impact on prey populations. Algae 35:4559.

Jang, S. H., Jeong, H. J. \& Chon, J. K. 2019. De novo transcriptome of the newly described phototrophic dinoflagellate Yihiella yeosuensis: comparison between vegetative cells and cysts. Mar. Biol. 166:104.

Jang, S. H., Jeong, H. J., Kwon, J. E. \& Lee, K. H. 2017a. Mixotrophy in the newly described dinoflagellate Yihiella yeosuensis: a small, fast dinoflagellate predator that grows mixotrophically, but not autotrophically. Harmful Algae 62:94-103.

Jang, S. H., Jeong, H. J., Moestrup, Ø., Kang, N. S., Lee, S. Y., Lee, K. H. \& Seong, K. A. 2017b. Yihiella yeosuensis gen. et sp. nov. (Suessiaceae, Dinophyceae), a novel dinoflagellate isolated from the coastal waters of Korea. J. Phy- 
col. 53:131-145.

Jeong, H. J., Kang, H. C., You, J. H. \& Jang, S. H. 2018a. Interactions between the newly described small- and fast-swimming mixotrophic dinoflagellate Yihiella yeosuensis and common heterotrophic protists. J. Eukaryot. Microbiol. 65:612-626.

Jeong, H. J., Lee, K. H., Yoo, Y. D., Kang, N. S., Song, J. Y., Kim, T. H., Seong, K. A., Kim, J. S. \& Potvin, E. 2018b. Effects of light intensity, temperature, and salinity on the growth and ingestion rates of the red-tide mixotrophic dinoflagellate Paragymnodinium shiwhaense. Harmful Algae 80:46-54.

Jeong, H. J., Lee, S. Y., Kang, N. S., Yoo, Y. D., Lim, A. S., Lee, M. J., Kim, H. S., Yih, W., Yamashita, H. \& LaJeunesse, T. C. 2014. Genetics and morphology characterize the dinoflagellate Symbiodinium voratum, n. sp., (Dinophyceae) as the sole representative of Symbiodinium clade E. J. Eukaryot. Microbiol. 61:75-94.

Jeong, H. J., Lim, A. S., Franks, P. J. S., Lee, K. H., Kim, J. H., Kang, N. S., Lee, M. J., Jang, S. H., Lee, S. Y., Yoon, E. Y., Park, J. Y., Yoo, Y. D., Seong, K. A., Kwon, J. E. \& Jang, T. Y. 2015. A hierarchy of conceptual models of red-tide generation: nutrition, behavior, and biological interactions. Harmful Algae 47:97-115.

Jeong, H. J., Lim, A. S., Lee, K., Lee, M. J., Seong, K. A., Kang, N. S., Jang, S. H., Lee, K. H., Lee, S. Y., Kim, M. O., Kim, J. H., Kwon, J. E., Kang, H. C., Kim, J. S., Yih, W., Shin, K., Jang, P. K., Ryu, J. -H., Kim, S. Y., Park, J. Y. \& Kim, K. Y. 2017. Ichthyotoxic Cochlodinium polykrikoides red tides offshore in the South Sea, Korea in 2014: I. Temporal variations in three-dimensional distributions of red-tide organisms and environmental factors. Algae 32:101-130.

Jeong, H. J., Yoo, Y. D., Kim, J. S., Seong, K. A., Kang, N. S. \& Kim, T. H. 2010. Growth, feeding, and ecological roles of the mixotrophic and heterotrophic dinoflagellates in marine planktonic food webs. Ocean Sci. J. 45:65-91.

Jeong, H. J., Yoo, Y. D., Seong, K. A., Kim, J. H., Park, J. Y., Kim, S., Lee, S. H., Ha, J. H. \& Yih, W. H. 2005. Feeding by the mixotrophic red-tide dinoflagellate Gonyaulax polygramma: mechanisms, prey species, effects of prey concentration, and grazing impact. Aquat. Microb. Ecol. 38:249-257.

Kang, H. C., Jeong, H. J., Jang, S. H. \& Lee, K. H. 2019a. Feeding by common heterotrophic protists on the phototrophic dinoflagellate Biecheleriopsis adriatica (Suessiaceae) compared to that of other suessioid dinoflagellates. Algae 34:127-140.

Kang, H. C., Jeong, H. J., Kim, S. J., You, J. H. \& Ok, J. H. 2018. Differential feeding by common heterotrophic protists on 12 different Alexandrium species. Harmful Algae 78:106-117.

Kang, H. C., Jeong, H. J., Ok, J. H., You, J. H., Jang, S. H., Lee, S. Y., Lee, K. H., Park, J. Y. \& Rho, J. -R. 2019b. Spatial and seasonal distributions of the phototrophic dinoflagellate Biecheleriopsis adriatica (Suessiaceae) in Korea: quantification using qPCR. Algae 34:111-126.

Karim, W., Nakaema, S. \& Hidaka, M. 2015. Temperature effects on the growth rates and photosynthetic activities of Symbiodinium cells. J. Mar. Sci. Eng. 3:368-381.

Kibler, S. R., Litaker, R. W., Holland, W. C., Vandersea, M. W. \& Tester, P. A. 2012. Growth of eight Gambierdiscus (Dinophyceae) species: effects of temperature, salinity and irradiance. Harmful Algae 19:1-14.

Kim, D. -I., Matsuyama, Y., Nagasoe, S., Yamaguchi, M., Yoon, Y. -H., Oshima, Y., Imada, N. \& Honjo, T. 2004. Effects of temperature, salinity and irradiance on the growth of the harmful red tide dinoflagellate Cochlodinium polykrikoides Margalef (Dinophyceae). J. Plankton Res. 26:61-66.

Klueter, A., Trapani, J., Archer, F. I., McIlroy, S. E. \& Coffroth, M. A. 2017. Comparative growth rates of cultured marine dinoflagellates in the genus Symbiodinium and the effects of temperature and light. PLoS ONE 12:e0187707.

Korea Hydrographic and Oceanographic Agency (KHOA). 2020. Available from: http://www.khoa.go.kr. Accessed Jul 9, 2020.

Laabir, M., Jauzein, C., Genovesi, B., Masseret, E., Grzebyk, D., Cecchi, P., Vaquer, A., Perrin, Y. \& Collos, Y. 2011. Influence of temperature, salinity and irradiance on the growth and cell yield of the harmful red tide dinoflagellate Alexandrium catenella colonizing Mediterranean waters. J. Plankton Res. 33:1550-1563.

LaJeunesse, T. C., Parkinson, J. E., Gabrielson, P. W., Jeong, H. J., Reimer, J. D., Voolstra, C. R. \& Santos, S. R. 2018. Systematic revision of Symbiodiniaceae highlights the antiquity and diversity of coral endosymbionts. Curr. Biol. 28:2570-2580.

Lee, C. -K., Park, T. -G., Park, Y. -T. \& Lim, W. -A. 2013. Monitoring and trends in harmful algal blooms and red tides in Korean coastal waters, with emphasis on Cochlodinium polykrikoides. Harmful Algae 30(Suppl. 1):S3-S14.

Lee, K. H., Jeong, H. J., Kang, H. C., Ok, J. H., You, J. H. \& Park, S. A. 2019a. Growth rates and nitrate uptake of cooccurring red-tide dinoflagellates Alexandrium affine and $A$. fraterculus as a function of nitrate concentration under light-dark and continuous light conditions. Algae 34:237-251.

Lee, S. K., Jeong, H. J., Jang, S. H., Lee, K. H., Kang, N. S., Lee, M. J. \& Potvin, É. 2014. Mixotrophy in the newly 
described dinoflagellate Ansanella granifera: feeding mechanism, prey species, and effect of prey concentration. Algae 29:137-152.

Lee, S. Y., Jeong, H. J., Kwon, J. E., You, J. H., Kim, S. J., Ok, J. H., Kang, H. C. \& Park, J. Y. 2019b. First report of the photosynthetic dinoflagellate Heterocapsa minima in the Pacific Ocean: morphological and genetic characterizations and the nationwide distribution in Korea. Algae 34:7-21.

Levinsen, H. \& Nielsen, T. G. 2002. The trophic role of marine pelagic ciliates and heterotrophic dinoflagellates in arctic and temperate coastal ecosystems: a cross-latitude comparison. Limnol. Oceanogr. 47:427-439.

Li, A., Stoecker, D. K. \& Coats, D. W. 2000. Spatial and temporal aspects of Gyrodinium galatheanum in Chesapeake Bay: distribution and mixotrophy. J. Plankton Res. 22:2105-2124.

Lim, A. S., Jeong, H. J., Ok, J. H. \& Kim, S. J. 2018. Feeding by the harmful phototrophic dinoflagellate Takayama tasmanica (Family Kareniaceae). Harmful Algae 74:19-29.

Lim, A. S., Jeong, H. J., Ok, J. H., You, J. H., Kang, H. C. \& Kim, S. J. 2019. Effects of light intensity and temperature on growth and ingestion rates of the mixotrophic dinoflagellate Alexandrium pohangense. Mar. Biol. 166:98.

López-Cortés, D. J., Núñez Vázquez, E. J., Dorantes-Aranda, J. J., Band-Schmidt, C. J., Hernández-Sandoval, F. E., Bustillos-Guzmán, J. J., Leyva-Valencia, I. \& FernándezHerrera, L. J. 2019. The state of knowledge of harmful algal blooms of Margalefidinium polykrikoides (a.k.a. Cochlodinium polykrikoides) in Latin America. Front. Mar. Sci. 6:463.

Matsubara, T., Nagasoe, S., Yamasaki, Y., Shikata, T., Shimasaki, Y., Oshima, Y. \& Honjo, T. 2007. Effects of temperature, salinity, and irradiance on the growth of the dinoflagellate Akashiwo sanguinea. J. Exp. Mar. Biol. Ecol. 342:226-230.

McBride, B. B., Muller-Parker, G. \& Jakobsen, H. H. 2009. Low thermal limit of growth rate of Symbiodinium californium (Dinophyta) in culture may restrict the symbiont to southern populations of its host anemones (Anthopleura spp.; Anthozoa, Cnidaria). J. Phycol. 45:855-863.

McClanahan, T. R., Ateweberhan, M., Muhando, C. A., Maina, J. \& Mohammed, M. S. 2007. Effects of climate and seawater temperature variation on coral bleaching and mortality. Ecol. Monogr. 77:503-525.

Montero, P., Pérez-Santos, I., Daneri, G., Gutiérrez, M. H., Igor, G., Seguel, R., Purdie, D. \& Crawford, D. W. 2017. A winter dinoflagellate bloom drives high rates of primary production in a Patagonian fjord ecosystem. Estuar. Coast. Shelf Sci. 199:105-116.
Nitschke, M. R., Davy, S. K., Cribb, T. H. \& Ward, S. 2015. The effect of elevated temperature and substrate on freeliving Symbiodinium cultures. Coral Reefs 34:161-171.

Ok, J. H., Jeong, H. J., Lim, A. S. \& Lee, K. H. 2017. Interactions between the mixotrophic dinoflagellate Takayama helix and common heterotrophic protists. Harmful Algae 68:178-191.

Ok, J. H., Jeong, H. J., Lim, A. S., You, J. H., Kang, H. C., Kim, S. J. \& Lee, S. Y. 2019. Effects of light and temperature on the growth of Takayama helix (Dinophyceae): mixotrophy as a survival strategy against photoinhibition. J. Phycol. 55:1181-1195.

Robison, J. D. \& Warner, M. E. 2006. Differential impacts of photoacclimation and thermal stress on the photobiology of four different phylotypes of Symbiodinium (Pyrrhophyta). J. Phycol. 42:568-579.

Rogers, J. E. \& Davis, R. H. 2006. Application of a new microculturing technique to assess the effects of temperature and salinity on specific growth rates of six Symbiodinium isolates. Bull. Mar. Sci. 79:113-126.

Roselli, L., Vadrucci, M. R., Belmonte, M., Ciciriello, P., Rubino, F., Ungaro, N. \& Caroppo, C. 2020. Two-stages bloom of Margalefidinium cf. polykrikoides in a Mediterranean shallow bay (Ionian Sea, Italy). Mar. Pollut. Bull. 151:110825.

Ruthrof, K. X., Breshears, D. D., Fontaine, J. B., Froend, R. H., Matusick, G., Kala, J., Miller, B. P., Mitchell, P. J., Wilson, S. K., van Keulen, M., Enright, N. J., Law, D. J., Wernberg, T. \& Hardy, G. E. S. J. 2018. Subcontinental heat wave triggers terrestrial and marine, multi-taxa responses. Sci. Rep. 8:13094.

Sakamoto, S., Lim, W. A., Lu, D., Dai, X., Orlova, T. \& Iwataki, M. 2020. Harmful algal blooms and associated fisheries damage in East Asia: current status and trends in China, Japan, Korea and Russia. Harmful Algae. Advanced online publication. https://doi.org/10.1016/j. hal.2020.101787.

Seong, K. A., Jeong, H. J., Kim, S., Kim, G. H. \& Kang, J. H. 2006. Bacterivory by co-occurring red-tide algae, heterotrophic nanoflagellates, and ciliates. Mar. Ecol. Prog. Ser. 322:85-97.

Seong, K. -T., Choi, Y. -H., Koo, J. H. \& Jeon, S. -B. 2014. Fluctuations and time series forecasting of sea surface temperature at Yeosu coast in Korea. J. Korean Soc. Mar. Environ. Energy 17:122-130.

Skovgaard, A., Hansen, P. J. \& Stoecker, D. K. 2000. Physiology of the mixotrophic dinoflagellate Fragilidium subglobosum. I. Effects of phagotrophy and irradiance on photosynthesis and carbon content. Mar. Ecol. Prog. Ser. 201:129-136. 
Spilling, K., Olli, K., Lehtoranta, J., Kremp, A., Tedesco, L., Tamelander, T., Klais, R., Peltonen, H. \& Tamminen, T. 2018. Shifting diatom: dinoflagellate dominance during spring bloom in the Baltic Sea and its potential effects on biogeochemical cycling. Front. Mar. Sci. 5:327.

Stoecker, D. K., Hansen, P. J., Caron, D. A. \& Mitra, A. 2017. Mixotrophy in the marine plankton. Annu. Rev. Mar. Sci. 9:311-335.

Taylor, F. J. R., Hoppenrath, M. \& Saldarriaga, J. F. 2008. Dinoflagellate diversity and distribution. Biodivers. Conserv. 17:407-418.

Wernberg, T., Smale, D. A., Tuya, F., Thomsen, M. S., Langlois, T. J., De Bettignies, T., Bennett, S. \& Rousseaux, C. S. 2013. An extreme climatic event alters marine ecosystem structure in a global biodiversity hotspot. Nat. Clim. Change 3:78-82.
Yih, W., Kim, H. S., Jeong, H. J., Myung, G. \& Kim, Y. G. 2004. Ingestion of cryptophyte cells by the marine photosynthetic ciliate Mesodinium rubrum. Aquat. Microb. Ecol. 36:165-170.

You, J. H., Jeong, H. J., Kang, H. C., Ok, J. H., Park, S. A. \& Lim, A. S. 2020a. Feeding by common heterotrophic protist predators on seven Prorocentrum species. Algae 35:6178.

You, J. H., Jeong, H. J., Lim, A. S., Ok, J. H. \& Kang, H. C. $2020 b$. Effects of irradiance and temperature on the growth and feeding of the obligate mixotrophic dinoflagellate Gymnodinium smaydae. Mar. Biol. 167:64.

Zheng, S., Wang, G. \& Lin, S. 2012. Heat shock effects and population survival in the polar dinoflagellate Polarella glacialis. J. Exp. Mar. Biol. Ecol. 438:100-108. 